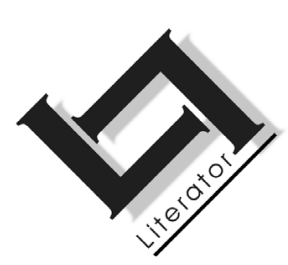

\title{
Boer-uitbeeldings in Franse jeugliteratuur tydens die Anglo-Boereoorlog ${ }^{1}$
}

\author{
J.E.T. Steyn \\ Departement Moderne Vreemde Tale \\ Universiteit van Stellenbosch \\ STELLENBOSCH \\ E-pos: jets@sun.ac.za
}

\begin{abstract}
Representations of the Boer in French youth literature during the Anglo Boer War

Representations of the "other" or alterity are to a large extent influenced by the historical context of the onlooker. When this historical context changes, it often happens that the representation of the "other" is adapted accordingly. This article provides a short overview of the way in which French representations of the Boers in youth novels written before the Anglo-Boer War differ from youth novels about the war.

Before the war the Boer is described as a Dutch descendant living in utmost, almost barbaric, simplicity. When the AngloBoer War breaks out, the Boer becomes an alter ego for the French who indirectly continue the French struggle against the British. This article discusses the way in which the French adapt their representation of the Boers in order for young French readers to identify with the Boers.
\end{abstract}

\section{Opsomming}

Boer-uitbeeldings in Franse jeugliteratuur tydens die AngloBoereoorlog

Voorstellings van die "ander" of die "vreemde" word grootliks beïnvloed deur die voorsteller se eie historiese konteks. Wan-

$1 \quad$ Hierdie artikel is gebaseer op navorsing gedoen vir die graad Maîtrise in moderne Franse letterkunde aan die Université François Rabelais in Tours, Frankryk (1993). 
neer hierdie konteks verander, gebeur dit dikwels dat die voorstelling van die "ander" ook aangepas word by hierdie veranderings. Hierdie artikel kyk kortliks hoedat die Franse voorstellings van die Boere verskil in jeugromans wat vóór die Anglo-Boereoorlog geskryf is van jeugromans wat oor die Anglo-Boereoorlog handel.

Vóór die oorlog word die Boer as 'n Nederlandse afstammeling beskryf wat byna agterlik en in uiterste eenvoud leef. Wanneer die Anglo-Boereoorlog uitbreek, word die Boer egter 'n soort alter ego vir die Franse wat indirek Frankryk se stryd teen die Britte voortsit. Hierdie artikel bespreek die manier waarop die Franse hulle voorstelling van die Boere aanpas sodat jong Franse lesers met die Boere kan identifiseer.

\section{Inleiding}

Binne die konteks van Europese imperialisme is die kwessie van die uitbeelding van die ander dikwels gesien as 'n onderdeel van die veld van objektiewe, wetenskaplike etnografie, joernalistieke kommentaar of fiksie. Klem is geplaas op die opteken van waargenome feite, maar volgens Said (aangehaal deur Anand, 2007:24) wys die postkoloniale teorie juis dat Westerse kennis en voorstellings van die nie-Westerse wêreld nie onskuldig was of op bestaande realiteite gebaseer was nie. Hierdie voorstellings het deel uitgemaak van die Weste se magsbeheptheid en imperiale avonture en die sogenaamde objektiwiteit van die voorstellings het juis verhoudings van ongelykheid en dominasie verbloem (Anand, 2007:24).

Fiktiewe en nie-fiktiewe voorstellings van die ander uit daardie tyd het tot 'n groot mate bestaan uit stereotipiese uitbeeldings en eensydige beskrywings van 'n groep of 'n kultuur wat gereduseer is tot 'n paar eenvoudige eienskappe wat nooit sal of kan verander nie (Anand, 2007:24). Stereotipering het die imperialisme op twee vlakke gedien. Eerstens het dit die idee van paternalistiese dominasie ondersteun en tweedens het dit, op psigiese vlak, die koloniste teen 'n ongemaklike skuldgevoel en die bewustheid van die ander se armoede beskerm (Anand, 2007:27).

'n Kronologiese studie van fiktiewe en nie-fiktiewe werke wat tot en met die einde van die negentiende eeu gepubliseer is en wat na Suid-Afrika in die algemeen en die Boere in die besonder verwys, toon 'n interessante waarneming. Dit toon dat die voorstelling van die Boer geleidelik gereduseer is tot stereotipes en dat die skrywers slegs sekere eienskappe en elemente gebruik het wat vir hulle eie ideologiese diskoers van belang was (Teulié, 2000:50). 
Wanneer Franse reisigers voor die tagtigerjare van die negentiende eeu gebiede besoek het wat deur die Boere gekoloniseer is, is die voorstelling van die Boere oorwegend dié van 'n argaïese samelewing wat in die grootste eenvoud leef (Teulié, 2000:51). Teulié (2000:51) verwys na Emile Montégut se L'Angleterre et ses colonies australes (1880). Hierdie publikasies is gemik op skoolkinders (die boek was toegeken as eerste prys vir Retoriek aan die Lycée Montpellier), en hierin word die Boer as 'n soort lewende fossiel voorgestel. Dit is interessant dat Montégut geen melding maak van die Boere se Franse herkoms nie.

On comprendra qu'il n'y ait guère de population plus originale dans le monde actuel que celle des Boers (les fermiers, les agriculteurs), les descendants des anciens colons hollandais, si nous disons qu'il n'en est aucune aujourd'hui [...] qui représente avec plus de pureté une population de l'ancien régime. Le Boer de 1878 est resté ce qu'il était en 1700, un Hollandais à l'ancienne mode qui serait un véritable revenant s'il lui était donné d'apparaître une heure dans sa patrie d'origine. (Montégut as quoted in Teulié, 2000:51.)

Julle sal verstaan dat daar nêrens 'n meer oospronklike bevolking ter wêreld bestaan as dié van die Boere nie (Boer beteken plaasboer of landbouer). Hulle is die afstammelinge van Hollandse koloniste en ons kan sê dat daar nêrens 'n bevolking is wat op 'n suiwerder manier die ou bedeling verteenwoordig as hulle nie. Die Boer van 1878 is presies net soos hy in 1700 was - 'n outydse Hollander wat as 'n spook aangesien sou word indien hy 'n uur lank in sy land van oorsprong sou verskyn.2

'n Ander Franse reisiger, Milbert (1812), wat die Kaap vroeg in die negentiende eeu besoek het, beskryf die inwoners van die Kaap, "hoofsaaklik van Nederlandse oorsprong", as baie ernstig, dog bedagsaam en innemend (Milbert, 1812:340).

\section{Vooroorlogse jeugliteratuur}

Die skrywer van hierdie artikel het vier Franse jeugromans bestudeer wat vóór die Anglo-Boereoorlog gepubliseer is. Volgens 
mnr. Noël Heard 3 moes daar nóg sulke jeugromans gewees het, maar aangesien hierdie romans hoofsaaklik vir kinders bedoel is, is hulle gewoonlik in klein opgaaf en op swak kwaliteit papier gedruk. Gevolglik het baie van hierdie romans verlore geraak.

In hierdie vooroorlogse romans speel die Boer 'n relatief onbeduidende rol (Verne, 1870). Hy word hoofsaaklik as 'n onverfynde karakter uitgebeeld (Picard, s.a.; Verne, 1884) of as 'n wrede, onopgevoede barbaar (Boussenard, 1884).

\subsection{Die Boer is gasvry, maar dis ook al}

In Les aventures de trois Russes et de trois Anglais dans l'Afrique australe (Verne, 1870) word slegs twee keer kortliks melding gemaak van Boere. Die eerste keer is wanneer die Anglo-Russiese span wetenskaplikes baie gul ontvang word deur 'n trekboer. Hierdie Boer is die hoof van 'n groot gesin en hy weier enige vergoeding vir sy gasvryheid. Volgens Corbey en Leerssen (1991:vii) was daar reeds vanaf die vroegste tye 'n soort waardering vir "andersheid" (otherness) - 'n waardering vir ongekunsteldheid, onskuld, vryheid van sosiale beperkings. Die skrywers sê voorts dat 'n ontmoeting met vreemdelinge ook tot 'n bewondering vir die universeel positiewe deug van gasvryheid kan lei en nie net vyandige wantroue en verkleinering nie. Die Odussee van Homerus is volgens Corbey en Leerssen (1991:vii) een lang getuienis van die idee dat gasvryheid aan vreemdelinge ' $n$ sentrale merker is van ware positiewe humaniteit, ongeag kulturele of sosiale agtergrond. In Verne (1870) is die Boer se gasvryheid die enigste positiewe eienskap wat beskryf word.

Die tweede keer wat Verne van die Boere melding maak, is wanneer die wetenskaplikes by Engelse sendelinge in Kolobeng oorbly.

Là se voyait encore la maison de Livingstone, telle qu'elle était lorsque le chasseur Baldwing (sic) la visita, c'est-à-dire ruinée et saccagée: car les Boers ne la respectèrent pas dans leur incursion de 1852. (Verne, 1870:143-144.)

Daar kon 'n mens nog Livingstone se huis sien, soos dit gelyk het toe die jagter, Baldwing (sic) dit besoek het, dit wil sê

3 Mnr. Heard van Déols, Frankryk, is 'n groot liefhebber van Suid-Afrika en 'n ywerige versamelaar van antieke boeke wat oor Suid-Afrika handel. Die outeur is hom baie dank verskuldig vir die gebruik van sy private biblioteek. 
verinneweer en geplunder, want die Boere het geen respek getoon tydens hulle strooptog van 1852 nie.

Verne het Suid-Afrika nooit self besoek nie, en hy baseer sekere van die gebeure in die roman op William Baldwin (Baldwin, 1863) se jagjoernale. Die aanhaling hierbo is bykans woord vir woord aangehaal uit Baldwin (1863:173) se Récits de chasse, asook die beskrywings van die Boer se gasvryheid en eenvoudige lewenswyse.

\subsection{Die Boer is 'n ruwe, onverfynde karakter}

In 'n ander vooroorlogse jeugroman, L'Héritage du Boer4 deur Abel Picard (s.a.), maak die leser kennis met twee broers, Jan en Hans van Blount. Jan is 'n skatryk boer in die Smithfield-distrik en sy broer is ' $n$ rower. Hans is bleek en blond en met sy groot lyf is hy 'n tipiese voorbeeld van 'n Hollander met suiwer bloed, van dié wat die Kaap gekolonialiseer het. Hy glo in min ander dinge as bloot sy eie fisiese krag (Picard, s.a.:8). Hans en Hendrik, sy Griekwa-metgesel, se bokvelbaadjies en stewels is in 'n ellendige toestand, maar hulle gewere dwing respek af onder die inwoners van die streek. Die indruk word in hierdie roman geskep dat die Boere taamlik brutale en ruwe mense is wat nie skroom om mekaar met messe by te dam oor ontevredenhede nie.

Jan van Blount se rykdom en duur klere (sy geborduurde kasmierserp, fyn klere en hoed) staan in skrille kontras met die eenvoud van sy woning: dit is 'n eenverdiepingkonstruksie wat met boomstamme aanmekaargetimmer is. Die plat dak het 'n lae muurtjie rondom waaragter Jan kan skuil in geval van 'n gewapende aanval. Arend, Jan se seun, slaap vanaf vierjarige ouderdom nie op 'n bed nie, maar op diervelle op die grond. Sy kussing is 'n leeukop se maanhare (Picard, s.a.:13). Al is Jan 'n baie ryk man, leef hy in byna agterlike eenvoud.

\subsection{Die Boer is gevaarlik}

'n Baie negatiewe beeld van die Boer word geskep in 'n jeugroman deur Louis Boussenard, Les aventures périlleuses de trois Français au pays des diamants (1884). In hierdie roman word die Engelse geprys as intelligent, gaaf, ordelik, goed georganiseerd - "oral waar

$4 \quad$ Hierdie roman het sonder publikasiedatum verskyn, maar die gebeure speel af in Smithfield in 1853. Geen melding word van die Anglo-Boereoorlog gemaak nie en die afleiding kan dus gemaak word dat die roman vóór die oorlog geskryf is. 
'n Engelsman die Union Jack plant, lyk dit asof die geluk homself naderhaas om aan hom gunste te bewys" (Boussenard, 1884:4).

Volgens Boussenard is die Boer 'n onopgevoede lummel met 'n onversadigbare drang na goud. Hy gaar groot hoeveelhede daarvan op sonder om dit ooit te gebruik of te spandeer. In hierdie roman maak die leser kennis met Klaas, Pieter en Cornelis, drie broers, barbaarse rowers en moordenaars. Boussenard sê dat die drie uitstekende skuts is, soos alle Boere, maar dat hulle diere jag vir kos met dieselfde gemak as waarmee hulle mense skiet (Boussenard, 1884:61).

Wat hulle fisiese voorkoms betref, is hulle kolosse van tussen 30 en 35 jaar oud. Die drie broers is "half-bison en half-seekoei" en amper ses voet lank. Hulle bolywe, wat lyk asof dit aan mense van 'n ander ras en 'n ander era behoort, is lank, breed, swaar en swak gevorm. Hulle arms is so gespierd dat hulle amper misvormd lyk. Die drie se gesigte is gebrand deur die Afrika-son en is breed, reëlmatig en goedig, selfs salig; maar daar is tog iets brutaals en boosaardigs te bespeur. Bruin vlekke, wat ewe goed dier- of mensbloed kan wees, is sigbaar op hulle smerige, geskeurde leerklere (Boussenard, 1884:62).

Hulle armoedige woonplek is net so ru soos hulle en is baie agterlik. Dit bestaan uit 'n paar regopstaande planke wat met 'n mengsel van klei en strooi aanmekaargehou word, en 'n dak van halfverrotte blare. Hulle slaap op 'n hoop blare in 'n hoek, sit op beesskedels met die horings wat dien as armleunings; die tafel is ' $n$ onbewerkte blok hout. Teen die muur staan drie enorme gewere en op die tafel is daar groot beeshorings elk met 'n seekoeivelhandvatsel, vol Kaapse brandewyn (Boussenard, 1884:63).

Boussenard (1884:519) meld dat die drie broers, ten spyte van hulle uitermatige wreedheid en barbaarsheid, tog baie godsdienstig en vroom is en altyd met groot respek van hulle ontslape ma praat. Hy verduidelik hierdie vreemde teenstrydigheid in 'n voetnota deur te sê dat die Boere - skaamtelose plunderaars, slawedrywers, genadelose moordenaars - groot waarde heg aan die gesin en hulle godsdiens baie geesdriftig beoefen (Boussenard, 1884:519). Volgens Anand (2007:31) het die uitbeelding van die "ander" as primitief en eenvoudig, dikwels hand aan hand gegaan met die wete dat daar elemente van onpeilbaarheid en misterie was wat veroorsaak dat die "ander" nie volkome begryp kan word nie. 
Boussenard verduidelik ook dat daar op daardie stadium twee tipes Boere in Suid-Afrika was: betroubare en onbetroubare Boere (Boers réguliers et irréguliers). Die betroubare Boere is dié wat in die Kaap agtergebly het. Hulle leef onder Britse gesag en is volgens Boussenard die soberste, fluksste en gasvryste mense wat 'n mens kan hoop om teë te kom (Boussenard, 1884:461). Die onbetroubares is dié wat weggetrek het na die Noorde en is soos die drie broers wat hierbo beskryf is.

Die Boer se karakter, volgens Boussenard (1884), is tot 'n groot mate toe te skryf aan sy Nederlandse herkoms.

Le Boer, en effet, qui incarne en sa lourde et placide personne l'astuce du Flamand, la ruse du Frison et la froide tenacité du Hollandais proprement dit, est un compère qu'il est à peu près impossible de prendre au dépourvu. Joignez à cela une absence complète de préjugés, une vigueur de bison et une adresse de Peau-Rouge, et vous conviendrez que le Néerlandais du Waal (sic) peut devenir, à l'occasion, un personnage des plus dangereux. (Boussenard, 1884:460.)

Met sy swaar en kalm geaardheid vergestalt die Boer die uitgeslapenheid van die Vlaming, die lis van die Fries en die kille hardnekkigheid van die Hollander, en dit is bykans onmoontlik om hom onverhoeds te betrap. Voeg hierby 'n totale afwesigheid van vooroordeel, die krag van 'n bison en die behendigheid van 'n Rooi Indiaan, en u sal saamstem dat die Nederlander van die Waal (sic) van tyd tot tyd 'n baie gevaarlike kêrel kan word.

\section{Die Boer se beeld verander}

Ten spyte van die negatiewe beeld wat in Boussenard $(1884)^{5}$ se roman geskep word, begin die voorstelling van die Boer ná 1881 in die Franse letterkunde vir die jeug en volwassenes te verander. $\mathrm{Na}$ die oorwinning van die Boere oor die Engelse in die Eerste Vryheidsoorlog begin die Franse hulle in 'n meer positiewe lig sien (Teulié, 2000:57). In L'Étoile du Sud beskryf Verne (1884) die Boer

5 Louis Boussenard publiseer in 1901 'n roman getiteld, Le capitaine Casse-Cou wat handel oor die Anglo-Boereoorlog. Hierdie werk is egter haas onbekombaar en die enigste uitgawe wat die outeur van hierdie artikel op die internet kon opspoor is in Russies. 'n Soektog op die webtuiste van die Bibliothèque Nationale de France het getoon dat die werk ook nie daar beskikbaar is nie. Dit sou interessant wees om te sien of Boussenard die Boere enigsins meer positief voorstel. 
steeds as ongekultiveerd en onopgevoed, maar gee nou aan sy vrou bekwaamhede en bevoegdhede wat vir haar man se gebrek aan kultuur vergoed.

L'homme est, dans le ménage, le (bread-winner), le gagneur de pain; il garde avec toute sa rudesse native, toute celle que lui impriment le métier en plein air, la vie de fatigues et de dangers. Au contraire, la femme prend pour son domaine, en plus des devoirs domestiques, la culture des arts et des lettres que dédaigne ou néglige son mari. (Verne, 1884:35.)

In die huishouding is die man die broodwinner. Hy het 'n ingebore ruheid, wat sy werk in die buitelug, sy uitputtende en gevaarlike lewe, op hom afdruk. Sy vrou, aan die ander kant, se domein bo en behalwe die huiswerk, is kuns en letterkunde wat deur haar man geminag of verwaarloos word.

Ten spyte van die Boer se eenvoud, stel Verne hom tog op 'n positiewe manier voor. Hy verwys na die Boere as goeie mense ("braves gens") wat 'n rustige bestaan voer op hulle uitgestrekte plase (Verne, 1884:35) en, soos in die vorige roman (Verne, 1870) meld hy die besondere gasvryheid van die Boer:

Partout les Boërs étaient les mêmes, hospitaliers, prévenants, désintéressés. L'étiquette du pays exige, il est vrai, qu'on leur offre une rémunération pour l'abri qu'ils donnent aux hommes et aux bêtes de voyage. Mais cette rémunération, ils la refusent presque toujours, et même ils insistent au départ pour qu'on accepte de la farine, des oranges, des pêches tapées. Si peu qu'on leur laisse en échange, un objet quelconque d'équipement ou de chasse, un fouet, une gourmette, une poire à poudre, les voilà ravis, quelque minime qu'en soit la valeur. (Verne, 1884:138.)

Oral was die Boere dieselfde: gasvry, bedagsaam, onselfsugtig. Die etiket van die land vereis, dit is waar, dat hulle vergoeding aangebied word vir die skuiling wat hulle aan mens en dier bied. Maar hulle wys altyd hierdie vergoeding van die hand, en dring selfs daarop aan om iets saam te gee wanneer jy vertrek: meel, lemoene, oorryp perskes. Wanneer jy vir hulle iets in ruil los, hetsy 'n stuk gereedskap of iets vir die jag - 'n sweep, armband, buskruit - is hulle in ekstase, hoe gering die waarde daarvan ook al mag wees.

Die verskuiwing van die Boer se landelikheid en eenvoud van 'n negatiewe na 'n positiewe eienskap kan vergelyk word met die verskuiwing wat daar van die Verligting na die Romantiek plaas- 
gevind het. Tydens die Verligting in die agtiende eeu is die stad gesien as plek van die rede en die wetenskap en die platteland as die gebied van onkunde en bygeloof. Die daaropvolgende Romantiese era vereer die natuur as goddelike krag en natuurlikheid word gesien as die hoogste waarde (Cieraad, 1991:22). Die neerhalende manier waarop na landelike mense verwys is (heidens, primitief of agterlik), maak plek vir 'n positiewe waardering. Daar is nou 'n besef van tradisie, harmonie, piëteit en hardwerkendheid (Cieraad, 1991: 23).

\section{Franse belangstelling in die Anglo-Boereoorlog}

Toe die Anglo-Boereoorlog in Oktober 1899 uitgebreek het, was daar in Frankryk en elders in Europa ' $n$ wye belangstelling en ondersteuning vir die twee Boererepublieke. In Frankryk is verskeie organisasies gestig ter ondersteuning van die Boere, soos die Association des Dames Françaises en die Union des Femmes de France wat bedrywig was met die verpleging van siekes en gewondes. Verder was daar ook Le Sou des Boers, die Ligue de la Patrie Française, die Ligue des Patriotes, die Comité de la Jeunesse Française en faveur du Transvaal en die Comité pour l'Indépendance des Boers (Nordbruch, 2000:20-21).

'n Mens kan vra waarom die Franse so gretig was om die Boere te ondersteun in hulle stryd teen die Britte. Om hierdie vraag te beantwoord, is dit belangrik om 'n oorsig te hê van wat in daardie tyd in Frankryk aan die gebeur was.

\subsection{Franse nasionale sentiment aan die einde van die negentiende eeu}

Frankryk is getraumatiseerd deur die nederlaag in die Frans-Pruisiese oorlog en die daaropvolgende Dreyfus-saak wat die nasie verdeel het, asook die vernedering na afloop van die Fashoda-insident van 1898 wat die Franse uit die Bo-Nylstreek verjaag het (Lugan, 1996:222). Hierdie gebeure het 'n strewe en hunkering terug na eenvoudiger, tradisionele waardes veroorsaak en daar is geglo dat 'n terugkeer na die bron of oorsprong sal help om 'n mate van sereniteit en waardigheid terug te kry (Teulié, 2000:57).

Daar het ook 'n sterk gevoel teen industriële uitbreiding geheers en in Frankryk is ' $n$ hernieude bewondering vir boere bespeur: landbouers wat voedsel vir die nasie verskaf. Sedert die Franse Revolusie van 1798 en die instelling van diensplig, het Frankryk dubbele voordeel uit sy burgers getrek: hulle dra by tot die ekonomie van die 
land én tot die verdediging van die vaderland. Om terselfdertyd boer te wees wat kos aan die nasie verskaf en soldaat wat die nasie beskerm, dwing bewondering af en word verpersoonlik in die mite van die Franse soldaat-boer, Nicolas Chauvin. Chauvin 6 was 'n baie patriotiese soldaat wat telkens, sodra die geveg verby was, teruggekeer het na sy plaas en sy werk hervat het wat deur die oorlog onderbreek is (Teulié, 2000:82). In een van die oorlogsromans vir die jeug (Lensia, s.a.) verduidelik een van die karakters aan sy Franse niggie dat die Boere by uitstek landbouers is, maar nie vir een oomblik weifel om die wapens op te neem wanneer hulle bedreig word nie.

Ici nous n'avons pas de palais, les Boers étant d'une simplicité patriarcale. D'ailleurs ce nom de Boers, sous lequel on les désigne, veut dire paysans. Ce sont des hommes libres, à l'âme fortement trempée. Doués de qualités transcendantes, ils se contentent d'être pasteurs et mettent toute leur fortune dans les pâturages et les troupeaux. Mais je vous ferai remarquer qu'ils ont la passion outrée de leurs droits et privilèges. Ils se feront tous écharper avant de permettre qu'on pose le pied sur leur territoire. L'indépendance, léguée par leurs ancêtres, leur est plus chère que la vie. Bons, hospitaliers, les Boers n'ont de haine que pour l'Anglais qui, toujours, les a poursuivis, chassés, traqués. (...) Les Boers ont une âme fière! (Lensia, s.a.:143.)

Hier het ons nie paleise nie, die Boere leef in patriargale eenvoud. Die naam Boer, waarmee ons hulle beskryf, beteken juis landbouer. Hulle is vry mense, met siele van staal. Hulle is tevrede om skaapwagters te wees en belê hulle hele fortuin in hulle weivelde en kuddes. Maar jy sal opmerk dat hulle 'n oordrewe passie vir hulle regte en voorregte het. Hulle sal hulself eerder uitmekaar laat skeur as om iemand toe te laat om hulle gebied binne te dring. Onafhanklikheid, wat hulle van hul voorouers geërf het, is vir hulle meer werd as die lewe self. Goeie, gasvrye mense wat niemand haat behalwe die Engelse nie, die Engelse wat hulle nog altyd agtervolg, gejaag en gejag het. (...) Die Boer het 'n trotse siel!

Volgens Teulié (2000:86) word hierdie eienskap van boer-soldaat aan die einde van die negentiende eeu sterk in Franse skoolboeke beklemtoon. Deur die oorlogs- en landbouvaardighede van die Fran-

6 Die term chauvinis, afgelei van Chauvin, beteken oorspronklik "'n dweepsieke bewonderaar van sy eie mense en vaderland" (Prinsloo, 2001:61). 
se ras op te hemel, leer kinders dat elke burger ' $\mathrm{n}$ rol het om in die verdediging van die land te speel en dat dit nie meer net die voorreg van die aristokratiese elite is nie. In die jeugromans kry die jong lesers te doen met konkrete dog fiktiewe voorbeelde van hoe selfs kinders 'n bydrae kan lewer om vir die land te veg en selfs te sterf.

\section{Die Boer word Frans}

'n Mens kan natuurlik die stelling maak dat hulle welbekende anglofobie ook die Franse aangespoor het om die Boere te ondersteun in 'n oorlog wat eintlik niks met Frankryk te make gehad het nie. Cyral (1902) plaas die Boere in dieselfde klas as Franse helde en ander nasies wat deur die Engelse uitgemoor is.

La guerre sud-africaine, la plus grande iniquité que l'Angleterre ait jamais commise: Honte à l'Angleterre: Bourreau de Jeanne d'Arc, de Napoléon, des Indes, de l'Irlande et des Boers. (Cyral, 1902:23.)

Die Suid-Afrikaanse Oorlog, die grootste ongeregtigheid wat Engeland ooit gepleeg het: Dis 'n skande, Engeland! Laksman van Jeanne d'Arc, Napoleon, Indië, lerland en die Boere.

Volgens Teulié (2000:81) vind daar 'n verskuiwing of oordrag in Franse mentaliteit plaas: deur die Boere moreel en finansieel te ondersteun, en deur die Franse vrywilligers in die Anglo-Boereoorlog tot nasionale helde te verklaar, verleng die Franse hulle eie stryd teen die Engelse deur middel van 'n "intermediêre" nasie - die Boere. Om hierdie oordrag suksesvol te maak, is dit belangrik dat die Boere 'n perfekte spieëlbeeld van die Franse word sodat die Franse met hulle kan identifiseer. Daar word gesoek na eienskappe wat die Boere en die Franse deel, sodat die Boere voorgestel kan word as die Franse se alter ego's. Eienskappe wat benadruk word, is dat dieselfde bloed in hulle are vloei, dat hulle dieselfde voorouers het en dat hulle identiese waardes en doelwitte het (Teulié, 2000:81). Arnoux (aangehaal in Teulié, 2000) gee 'n goeie opsomming van die Boer se karakter en meld ook die bydrae wat die Boer se Franse herkoms lewer.

Le Boër représente la fusion des races française et hollandaise; d'une part la vivacité, l'esprit et la générosité des sentiments, d'autre part la fierté personnelle et la force de la résistance; en commun, la ferveur religieuse, une sorte de hauteur artistocratique dans le caractère, l'exaltation de l'individu dans l'isolement des fermes, la lutte quotidienne contre le climat et les bêtes fauves, la ferme cohésion de la famille où le père 
remplit l'office de pasteur et de vrai patriarche, enfin, la défiance à l'égard de toute autorité, la haine de l'Anglais. (Teulié, 2000:106-107.)

Die Boer verteenwoordig die samesmelting van die Franse en Hollandse rasse; aan die een kant is daar lewenslus, geesdrif, gevoelvolheid, en aan die ander kant persoonlike trots en standvastigheid. Wat hulle in gemeen het, is diepgewortelde godsdienstigheid, 'n soort aristokratiese verhewendheid, die verheerliking van die individu op hul plase waar hulle 'n daaglikse stryd voer teen die klimaat en wilde diere. Hulle is hegte gesinne met die pa wat die rol van dominee en patriarg vervul en dan ook met minagting vir enige soort outoriteit en haat vir die Engelse.

\section{Oorlogsromans vir die jeug}

Daar is min bekend oor die outeurs van hierdie werke en dit is nie bekend of enigeen van hulle Suid-Afrika ooit besoek het nie. Die afleiding kan gemaak word dat hulle beskrywings van die Boere berus op wat hulle daardie tyd in koerante en ander geskrifte gelees, of op foto's en sketse gesien het. Hulle het ook gebruik gemaak van reisjoernale, dagboeke en romans wat vóór die oorlog gepubliseer is.

Van die tien jeugromans oor die Anglo-Boereoorlog wat die skrywer van hierdie artikel kon bestudeer, is een in 1899 gepubliseer en 'n ander in 1912. Die ander agt het sonder publikasiedatums verskyn.

In die romans word omtrent geen melding gemaak van werklike veldslae nie en dit is asof die oorlog bloot as agtergrond dien om sekere eienskappe van die Boer te beklemtoon. In al die romans kom ook kinderkarakters voor en dit is logies dat hierdie karakters, met hulle moedigheid en patriotisme, aan die jong Franse lesers voorgehou word as navolgenswaardige voorbeelde.

Behalwe in die geval van Boussenard se roman, word die Boer in vooroorlogse jeugromans voorgestel as gasvry, goed en onskuldig, dog agterlik en ongekultiveerd. In die oorlogsromans vir die jeug het die Boer steeds dieselfde, stereotipiese eienskappe, maar sy sogenaamde agterlikheid word nou in 'n positiewe lig gestel. Hy word eerder gesien as 'n soort edel barbaar wat nie deur die stad en die beskawing bederf is nie. Daar word ook in hierdie romans, in teenstelling met die vooroorlogse romans, melding gemaak van die Franse oorsprong van die Boere. 


\subsection{Franse oorsprong van die Boere}

In Franse skoolhandboeke wat aan die einde van die negentiende eeu gepubliseer word, word duidelik gemeld dat die Boere deels van Franse oorsprong is.

La population blanche était composée de fermiers - on les a appelés les Boers, c'est-à-dire les paysans - gens énergiques, descendants des colons hollandais et aussi de protestants français venus dans l'Afrique du Sud après la révocation de l'Edit de Nantes. (...) Hollandais et Français d'origine, tous protestants puritains, les Boers ont été les premiers colons de l'Afrique australe. Pour échapper à la domination anglaise, ils se sont établis sur les plateaux de l'intérieur, le Veld, qu'ils ont conquis au prix de guerres incessantes contre les belliqueuses tribus nègres des Zoulous et des Basoutous. Là, dans leurs vastes fermes, très éloignées les unes des autres, ils mènent une existence patriarcale et presque biblique. (Malet et Isaac aangehaal in Teulié, 2000:89-90.)

Die wit bevolking het bestaan uit landbouers - ons het hulle Boere genoem, dit beteken plattelanders - energieke mense, afstammelinge van Hollandse koloniste en ook van Franse protestante wat na Suid-Afrika verhuis het na die herroeping van die Edik van Nantes. (...) Die Boere, Hollanders en Franse van oorsprong, almal puriteinse protestante, was die eerste koloniste van Suider Afrika. Om aan Engelse oorheersing te ontsnap, het hulle op die vlaktes in die binneland gaan woon, in die Veld wat verower is na eindelose oorloë teen die veglustige swart stamme Zoeloes en Basoetoes. Daar, op hulle groot plase, ver van mekaar verwyderd, voer hulle 'n patriargale en amper Bybelse bestaan.

\section{Die Boer soos voorgestel in die jeugromans}

In hierdie afdeling word slegs 'n paar van die Boere-eienskappe, bestudeer soos voorgestel in die jeugromans.

\subsection{Fisiese voorkoms}

In die romans van Gysels (s.a.) en Saint-Yves (s.a.) is beskrywings van Presidente Steyn en Kruger en Generaals Joubert en Cronjé. Hulle word beskryf as verteenwoordigend van die hele Boereras:

Le Président Steyn est le type parfait de l'Africander: une taille d'un mètre quatre-vingts, un buste puissant, des épaules bien découplées et surmontées d'une tête large et forte; des yeux 
clairs et grands, un nez rectiligne et accusé, une abondante barbe noire. (Saint-Yves, s.a.:132.)

President Steyn is die perfekte voorbeeld van die Afrikaner: een meter tagtig lank, 'n forse bolyf, goedgevormde skouers met 'n groot en sterk kop, groot, helder oë, reguit neus en 'n welige swart baard.

[Le général Joubert a] une carrure massive et puissante comme tous les Boers, un front haut et très découvert, le nez grand et régulier, une barbe longue et grisonnante dont les fils d'argent retombent sur une large poitrine, le regard plutôt doux et triste, mais avec une réelle expression de franchise. (Saint-Yves, s.a.:261.)

[Generaal Joubert] is massief en sterk gebou soos al die Boere, 'n hoë, oop voorkop, lang reguit neus en 'n lang, gryswordende baard wat tot op sy breë bors hang, 'n sagte, hartseer, dog eerlike kyk in sy oë.

Die fiktiewe karakters lyk baie eenders. Hulle is fisies groot, het baarde, ligte oë en oop, eerlike gesigte. David [sic] Grobler met sy groot, lang lyf, deurmekaar hare en baard, bruingebrande gesig en intelligente oë is ' $n$ tipiese boer van die Oranje Vrystaat (Améro, s.a.:15). Walter Pietrik (Lensia, s.a.:172) is lank en skraal met 'n aangename gesig. Hy is ' $n$ toonbeeld van krag, goedheid en waardigheid. Sy blonde hare en baard versag sy gesig waarop intelligensie en lojaliteit te bespeur is (Lensia, s.a.:172).

Die bewondering vir die grootte en krag van die Boer word goed saamgevat in Les libres Burghers (Saint-Yves, s.a.) waar die karakter, Majoor Von Filfill, 'n Pruisiese vrywilliger, die volgende opmerking oor die Boere maak:

... des hommes superbes, six pieds, pas moins (...) Vos balles Lebel (...) perçaient au Dahomey un arbre et le nègre qui s'abritait derrière; mais je doute qu'elles puissent traverser un Boer. (Saint-Yves, s.a.:46.)

... manjifieke manne, niks minder as ses voet lank nie (...). Julle Lebel-koeëls het in Dahomey die boom en die swarte wat daaragter geskuil het, deurboor, maar ek twyfel of hulle deur 'n Boer sal kan skiet.

\subsubsection{Franse Boere en Nederlandse Boere}

Dit is interessant dat sommige van die skrywers 'n onderskeid tref tussen Boere van Nederlandse en van Franse oorsprong. Oor gene- 
raal Louis Botha word gesê dat hy 'n Franse voorkoms het en dus amper 'n beskaafde Boer is (Saint-Yves, s.a.:203). In Un héros de quinze ans (Dex, 1912) is een van die karakters 'n Boer van Nederlandse oorsprong. Hy is 'n reus van oor die sewe voet en sy gespierde lyf is in proporsie, al is sy skouers geweldig breed. 'n Mens hou dadelik van hom, van sy kalm en eerlike Vlaamse gesig en die sagte kyk in sy blou oë. Sy hele wese straal buitengewone krag uit, maar sy oordrewe fisiese krag word gebalanseer deur sy kalm geaardheid en die sagtheid van sy oë. Sy vriend, van Franse oorsprong, het 'n groot neus bo sy moedswillige mond en sy swart oë glinster ondeund. Hy is ook groot en sterk, dog ietwat fyner van vorm (Dex, 1912:18). Hy is dan ook die een wat slim planne beraam om die Engelse te uitoorlê terwyl sy Nederlandse vriend die fisiese krag verskaf om hierdie planne uit te voer.

Léra (s.a.) tref ook hierdie onderskeid in Les petits Boers. Die kindertjies van Nederlandse oorsprong, die Ozerpooms, is blond en fris terwyl die kind van die buurplaas, Georgy Duplessis, 'n Hugenoteafstammeling, bruin hare het met lewendige, intelligente oë. Hy is skraler en minder aktief as die Ozerpooms, maar presteer beter op skool. Wanneer die kinders wegsluip om saam met hulle pa's en ouer broers te gaan veg, is dit die Ozerpooms wat baie goed kan perdry en weet hoe om in die veld te oorleef terwyl Georgy, wat meer tyd agter sy boeke spandeer, meer kennis het van die geografie.

Dit wil dus voorkom asof die twee outeurs 'n soort simbiotiese verhouding tussen die Boere van Nederlandse en Franse oorsprong beskryf: die "Franse Boer" is die brein wat die planne maak, en die "Nederlandse Boer" is die liggaam wat hierdie planne uitvoer. Dit is in ooreenstemming met die groot waarde wat die Franse aan geleerdheid en intelligensie heg.

\subsection{Eenvoudige lewenswyse}

Die Boer se eenvoudige lewenswyse wat in vooroorlogse werke dikwels verduidelik is as ' $\mathrm{n}$ soort agterlikheid, word in die oorlogsromans geprys. Sevin-Desplaces (s.a.) gee 'n opsomming van hierdie leefwyse.

Pour s'établir (...) le Boer choisit une plaine un peu ondulée de deux à vingt mille arpents d'étendue. II y arrive dans son chariot avec femme et enfants, quelques ustensiles, une Bible qui est toute sa bibliothèque, des bœufs et des moutons. II place sa maison auprès d'une source, à dix mille (sic) environ de son 
plus proche voisin, puis il construit des enclos pour ses troupeaux et se fait un jardin qu'il irrigue. Un carré de cinquante à cent arpents est ensemencé en froment ou en maïs. Les troupeaux se multiplient sans effort. S'il est ambitieux, il y ajoute des autruches (...) il vit dans l'abondance. Le Boer n'a pas hâte de s'enrichir; il ne désire pas changer. II n'a que des besoins qu'il peut satisfaire; il ne demande qu'à vivre isolé. L'obéissance qu'il réclame de se enfants, il l'exige aussi de ses serviteurs. Sans enthousiasme, avec l'horizon intellectuel le plus borné, il a l'esprit pratique qui convient au pionnier de la civilisation Africaine. (Sevin-Desplaces, s.a.:489.)

Om homself te vestig, kies die Boer 'n golwende stuk veld van omtrent twee tot twintig duisend akker. Hy kom daar aan in sy wa met sy vrou en kinders, 'n paar stukke gereedskap, 'n Bybel wat sy hele biblioteek uitmaak, beeste en skape. Hy bou sy huis naby 'n fontein, omtrent tien myl vanaf sy naaste bure af. Dan bou hy 'n kraal vir sy kuddes en lê 'n tuin aan wat hy besproei. Hy plant mielies of koring. Die kuddes teel moeiteloos aan. As hy ambisieus is, mag hy dalk volstruise ook byvoeg (...) Hy leef in oorvloed. Die Boer is nie haastig om homself te verryk nie; hy hou nie van verandering nie. Sy enigste behoeftes is dié wat hy kan bevredig. Al wat hy verlang is om op sy eie te leef. Hy vereis dieselfde gehoorsaamheid van sy kinders as van sy werkers. Sonder entoesiasme, met 'n baie beperkte intellektuele horison, het hy die soort praktiese geaardheid wat gepas is vir 'n pionier van die Afrika beskawing.

Dex (1912:19) meld op 'n lofwaardige manier dat die Boer, man/ vrou, baie min nodig het vir sy/haar daaglikse bestaan. Dit kom ooreen met wat Lensia (s.a.:170) sê dat die Boer, soos al die Transvaalse Boere, homself beperk tot die nodige en geen tyd het vir oordadigheid nie. In dieselfde roman word 'n Franse immigrant getref deur die eenvoud van President Paul Kruger se woning. Dit is slegs aan die teenwoordigheid van die wagte wat 'n mens kan agterkom dat daar 'n belangrike persoon in die huis woon (Lensia, s.a.:144).

\subsection{Godsdienstigheid}

Dit mag vreemd voorkom dat die katolieke Franse die protestantse Boere ondersteun en boonop die Calvinistiese Boere prys vir hulle godsdienstigheid. In Frankryk was daar vir eeue 'n noue band tussen kerk en staat, maar tydens die Derde Republiek (1871-1940) het daar 'n stryd ontstaan oor sekulariteit, wat gelei het tot die skeiding van kerk en staat in 1905. Die feit dat die Boere terselfdertyd vurige republikeine en diep godsdienstig is, dien as model vir die 
Franse wat glo dat hierdie twee aspekte nie onversoenbaar is nie (die linksgesinde, meer anti-kerklike Franse, ondersteun steeds die Boere, maar konsentreer meer op hulle republikeinse waardes; Teulié, 2000:61).

In die jeugromans word die Boere se geloof geprys en hierdie aspek, tesame met die pastorale en patriargale elemente van die gemeenskap, skep die indruk dat hulle, soos die Jode, die uitverkore volk van God is.

Die Boer word voorgestel as iemand wat veg met die Bybel in die een hand en die geweer in die ander. Geen besluit word geneem sonder om eers daaroor te bid nie, en selfs op die slagveld word elke dag begin en afgesluit met Skriflesing en gebed.

Die Bybel is dikwels die enigste boek in die huis (Sévin-Desplaces, s.a.:489). Die groot Familiebybel word van geslag tot geslag oorgedra en die leeromslag en vergeelde bladsye is ' $n$ teken van gereelde gebruik. In die geval van die Retiefs (Saint-Yves, s.a.:14), is die Bybel al vir vier geslagte in die familie se gebruik. In dieselfde roman beveel die ou patriarg sy seun, Pieter, om te lees wat in die Bybel staan wanneer laasgenoemde die plaas wil verruil vir die stad. Wanneer Pieter aan die einde van die roman na die plaas terugkeer na 'n stormagtige verblyf in Johannesburg, ontvang sy pa hom met ope arms terug, "omdat die Boek dit beveel" (Saint-Yves, s.a.:273), soos in die gelykenis van die verlore seun.

Wanneer die bejaarde Pieter Grobler (Améro, s.a.:41-42) twyfel of hy ook moet gaan veg, vind hy sy antwoord in die heilige Skrif en sluit hom by 'n kommando aan.

Om 'n verklaring te vind vir abnormale situasies wend die Boere hulle ook tot die Boek. Wanneer 'n vreemde gedierte sy verskyning op die Ozerpooms se plaas maak, gee 'n buurman sy verduideliking:

Sou dit nie die verskriklike Leviatan wees waarmee die Bybel ons dreig nie? Hierdie dier is beslis deel van die Helse Magte; kom ons wees versigtig en gaan nie te naby nie. (Léra, s.a.:20.)

Die "ondier" word doodgemaak en hulle vind uit dit was 'n wolf wat sy kop in 'n pot gedruk het en dit nie weer kon uitkry nie.

Verder glo die Boere dat niks gebeur "as dit nie deur die Here beveel is nie" (Dex, 1912:17) en daarom aanvaar hulle voor- en teenspoed met dieselfde gelatenheid. 


\section{Ten slotte}

Van Alphen (1991:1) verduidelik dat identiteit en die vreemde (altérité) betrekking het op konkrete historiese situasies en gesien moet word in die konteks van die vooroordele wat binne daardie historiese situasies bestaan. Dit wil sê, die konsep/idee van identiteit en die vreemde kan verander soos wat die historiese situasie verander. Omdat die kyker of verteller se oogpunt verander, verander die manier waarop hy die "ander" beskou. Dit kom duidelik na vore in die geval van die verhale wat in hierdie artikel bespreek is.

In die vooroorlogse jeugromans word die Boer hoofsaaklik as 'n eenvoudige, ruwe, onbeskaafde en soms wreedaardige karakter uitgebeeld wat tog gasvry en godsdienstig is. Dit mag wees omdat Frankryk op daardie stadium nog sy mission civilatrice in gedagte gehad het. Daarvolgens het meer beskaafde, ontwikkelde volke wat 'n hoër doel in die lewe het, hulself die reg toegeëien om minder beskaafde volke te koloniseer en selfs op te voed (Said, 2008:333).

Tydens die Anglo-Boereoorlog word die Boer 'n handige voorbeeld van 'n klein volkie wat bereid is om 'n groot mag aan te vat en sy eienskappe kry nuwe waarde. Sy ongekunsteldheid en eenvoud word nie meer as tekens van verval en agteruitgang gesien nie, maar as voorvaderlike en partriargale deugde. Ongeletterdheid en gebrek aan belangstelling in kuns en kultuur beteken nie meer barbarisme nie, maar dui op 'n samelewing wat fokus op natuurlike behoeftes wat vir oorlewing nodig is. Die Boer se Calvinisme dui nie meer op onverdraagsaamheid nie, maar op sy gehoorsaamheid aan goddelike voorskrifte en sy aanvaarding van God se wil. Die Boer se beskerming en bewaring van republikeinse waardes en die verdediging van die geboorteland teen die Engelse, maak van die Boer 'n navolgenswaardige voorbeeld vir die Franse wat hulle nasionale trots wil herwin.

\section{Geraadpleegde bronne}

AMÉRO, C. s.a. Jan le Boer. Poitiers: Société Française d'imprimerie et de Librairie.

ANAND, D. 2007. Western colonial representations of the other: the case of exotica Tibet. http://staff.bath.ac.uk/ecsda/DAnandNPSArticleMar07.pdf Date of access: 11 Nov. 2009.

BALDWIN, W.C. 1863. African hunting: from Natal to the Zambesi. London: Bentley.

BIBLIOTHËQUE NATIONALE DE FRANCE. http://ccfr.bnf.fr/portailccfr/servlet/ LoginServlet Datum van gebruik: 27 Jun. 2009. 
BOUSSENARD, L. 1884. Aventures périlleuses de trois Français au pays des diamants. Paris: Marpon \& Flammarion.

CIERAAD, I. 1991. Traditional folk, industrial masses. (In Corbey, R. \& Leerssen, J. Th., eds. Alterity, identity, image: selves and others in society and scholarship. Amsterdam-Atlanta: Rodopi. p. 21-23.)

CORBEY, R. \& LEERSSEN, J. Th., eds. 1991. Alterity, identity, image: selves and others in society and scholarship. Amsterdam-Atlanta: Rodopi.

CYRAL, H. 1902. France et Transvaal: l'opinion française et la guerre SudAfricaine. Paris: Société d'éditions littéraires.

DEX, L. 1912. Un héros de quinze ans. Paris: Librairie Hachette.

GYSELS, L. s.a. Sur le champ. Poitiers: Société Française d'imprimerie et de librairie.

LENSIA, J. s.a. Emigrée au Transvaal. Paris: Société Française d'imprimerie et de Librairie.

LÉRA, M. s.a. Les petits boers: épisode de la guerre du Transvaal en 1900. Paris: Libraire Gedalge.

LUGAN, B. 1996. Ces Français qui ont fait l'Afrique du Sud. Paris: Bartillat.

MILBERT, M.J. 1812. Voyage pittoresque à l'lle-de-France, au Cap de BonneEspérance et à l'lle de Tériffe. Tome deuxième. Paris: Nepveu.

NORDBRUCH, C. 2000. Vir vryheid en reg: buitelanders aan boerekant tydens die Anglo-Boere Oorlog 1899-1902. Pretoria: Kontak Uitgewers.

PICARD, A. s.a. L'Héritage du Boer. Paris: Librairie d'éducation de la jeunesse.

PRINSLOO, A.F. 2001. Feite, flaters, fiksie. Kaapstad: Human \& Rousseau.

SAID, E.W. 2008. The clash of definitions. (In Alcoff, L.M. \& Mendieta, E., eds. Identities. Oxford: Blackwell. p. 333.)

SAINT-YVES, G. s.a. Les libres burghers. Tours: Maison Alfred Mame.

SÉVIN-DESPLACES. s.a. Les vaillants boers. Paris: Hatier.

TEULIÉ, G. 2000. Les Afrikaners et la guerre Anglo-Boer (1899-1902): étude des cultures populaire et de mentalités en présence. Université PaulValéry - Montpellier III: CERPANAC.

VAN ALPHEN, E. 1991. The other within. (In Corbey, R. \& Leerssen, J. Th., eds. Alterity, identity, image: Selves and others in society and scholarship. Amsterdam-Atlanta: Rodopi. p. 1.)

VERNE, J. 1870. Les aventures de trois Russes et de trois Anglais dans l'Afrique australe. Genève: Éditions Bellerive.

VERNE, J. 1884. L'Étoile du Sud. Genève: Éditions Bellerive.

\section{Kernbegrippe:}

Anglo-Boereoorlog

Boere, voorstellings van

Frankryk

identiteit

jeugromans 


\section{Key concepts:}

Anglo Boer War

Boers, representation of

France

identity

youth novels 